\title{
Dissocial Personality Traits and Past Experiences Matter in How People Perceive the Police
}

\author{
Charles Tochukwu Orjiakor ${ }^{1} \cdot$ Moses Onyemaechi Ede ${ }^{2}$ (D) $\cdot$ Chigozirim M. Emebo $^{1}$ \\ Published online: 29 August 2020 \\ (C) Society for Police and Criminal Psychology 2020
}

\begin{abstract}
The study investigated the contributions of dissocial traits and experience with the police to police perception. Participants $(261$ : males $=115$, females $=146$, mean age $=25.87)$ completed psychometric measures deviant personality traits, police perception, and experience with the police. Regression analysis was used to examine relationship patterns. Results indicated that people detested the police as they got older $(\beta=-0.19, t=-2.06, p=0.04)$. Also, having an encounter was associated with more negative perception of the $(\beta=-0.16, t=-1.97, p=0.04)$. Among the dark triad traits, only narcissism predicted police perception such that higher narcissism traits was associated with higher negative perception of the police $(\beta=-0.46, t=-2.21$, $p=0.03$ ). Findings seem to suggest that the police, especially in Nigeria, needs to do more to improve their connections with citizens; albeit, individual personality disposition matters, and should be a potential issue to consider when the police deals with citizens.
\end{abstract}

Keywords Dissocial traits $\cdot$ Experience $\cdot$ Police $\cdot$ Police perception

\section{Introduction}

Police organizations work to ensure law and order in society, but in addition, strive to ensure that the public that they serve, trust them and at least perceive them to be effective (Cheng 2015). However, the police, especially in developing countries such as Nigeria, have a poor reputation and are considered one of the weakest institutions (Chatham House 2010). Abuse, torture, extortion, violence, elite defense, bribery, and corruption are often reported by local and international observers (Andvig and Fjeldstad 2008; Amnesty International 2014; Chatham House 2010; Human Rights Watch 2005, 2010; Obe and Odesola 2008). Little wonder, Nigeria ranked worst in a global ranking of policing that considered among other measures, the public view of the police (International Police Science Association [IPSA] 2016). Though it may seem obvious that the notorious abusive style and practices associated with the Nigerian police could be the reason as to

Moses Onyemaechi Ede moses.ede@unn.edu.ng

1 Department of Psychology, Faculty of the Social Sciences, University of Nigeria, Nsukka, Nigeria

2 Department of Educational Foundations (Guidance and Counselling Unit), Faculty of Education, University of Nigeria, Nsukka, Nigeria why they are poorly perceived, an empirical research into factors that contribute to perception of the police is needed. However, studies regarding what fuels this poor reputation are scarce. In the current study, we aim to examine factors that contribute to the poor perception of the police in Nigeria.

Abusive/negative attitudes and actions meted from the police toward citizens will certainly earn the police negative perceptions from citizens. Even relatively minor wrongdoings by the police have been found to impact attitude toward the police (Smith and Hawkins 1973). People who are dissatisfied with the police are less likely to contact them or provide officers with information about criminal activity (Decker 1985). Thus, negative perceptions of the police contribute to a cycle of reduced police effectiveness, increased crime, and further distrust of the police. Conversely, having positive/favorable contacts with the police improves perceptions of the police (Dean 1980; Thomas and Hyman 1977; Smith 1991; Worrall 1999). Citizens' perception of the police have been reported to vary such that people who initiated contact with the police had more favorable perception compared to people whose contact was initiated by the police (Cheurprakobkit 2000). However, Cheurprakobkit (2000) also found that as contact with the police increased, people became less satisfied with police performance. In this study, we contend that in Nigeria, the experience one had while in contact with the police contributes to how favorable perceptions of the police would be. 
The perception of the police is however not limited to police (mis)doings. Attitude toward, and perceptions about the police are also influenced by demographic characteristics as well as individual psychological dispositions (Lee and Gibbs 2015; MacDonald et al. 2007; Zhao et al. 2014).Though the contributions of personality to police perception has been scarcely explored, Johnson et al. (1981) found that personality dispositions influenced attitudes toward authority figures such as parents, the police, and government. Also dissocial personality traits such as psychopathy have been found to affect general lifestyles (Eze et al. 2020), as well as the perception of procedural justice (Augustyn and Ray 2016). The dark triad (of psychopathy, narcissism, and Machiavellianism) is a more robust, widely researched constellation of dissocial personality traits, that is yet to be explored in relation to the perception of the police.

Narcissism is characterized by grandiosity, pride, egotism, and a lack of empathy (Konut 1977). Machiavellianism is characterized by manipulation and exploitation of others, a cynical disregard for morality, and a focus on self-interest and deception (Jacobwitz and Egan 2006). Psychopathy is characterized by enduring antisocial behavior, impulsivity, selfishness, callousness, and remorselessness (Skeem et al. 2011). The dark triad has been recently found to influence specific antisocial behaviours such as problem gambling (Onyedire et al. 2019), as well as generic ideological attitudes and social worldviews (Zeigler-Hill et al. 2020). We contend that these traits could also contribute to how the police is perceived.

Global challenges in 2020 have provoked more discussions about police organisations and their approaches in discharging their duties. Video images showing events leading to the death of George Floyd in the United States of America sparked massive outrage and calls for institutional reformations. There was a knock-on effect on other police instituions in Europe and beyound triggering the Black Lives Matter march globally. Ironically, the police is still expected to effectively manage the negative fallouts arising from such protests, such as destructions and looting of property. In Nigeria and indeed many African countries, there are several accounts of police brutality as the police tries to enforce lockdown measures arising from the corona virus pandemic (British Broadcasting Cooperation 2020; Egwu 2020). Understanding factors that influence how people perceieve the police will help inform police organisations on the necessary changes they have to make in building confidence and elicitng coorporation with the public so as to effectively deliver their critically needed services. Johnson and Olukayode (2014) reported that public support and cooperation will significantly enhance police performance in crime management in the Nigerian society. In the current study, we specifically explore the contributions of dissocial personality traits and past experiences with the police to the perception of the police in Nigeria. We hypothesize that 1) dissocial triats will not significantly predict the way the Nigerian police is perceived; 2) that experience with the police will not predict how people perceive the police.

\section{Method}

\section{Ethical Approval}

The researchers obtained written approval letter from the ethics committee of their institution. The researchers adhered to ethical standard of American Psychological Association when conducting study with human participants (American Psychological Association, 2010).

\section{Participants}

Three hundred participants were recruited for the study; however, only 261 (females $=55.9 \%$ ) participants validly completed the questionnaires. University students made up $65.9 \%$ ( $n=172)$ of the sample and were accidentally sampled across the 9 faculties in the University of Nigeria. Also, 89 employees of different public and private organizations were conveniently recruited to participate in the study. Participants were aged between 17 and 65 years (mean age = 25.87, $\mathrm{SD}=8.11$ ) and have completed at least, secondary level education.

\section{Instruments}

In addition to the demographic section, statements investigating exposure to crime (4-items), sample items include "I have witnessed or been a victim of a crime in the past 2 years", "A member of my household has been a victim of crime in the past 2 years", "How often do you use the media to get news on crimes" etc., age, gender, religion, denomination, marital status, highest qualification, locality, occupation, and substances used. The second part contained the measure of the variables of dissocial traits, experience, and perception.

Short Dark Triad The dark triad scale was developed by Jones and Paulhus (2014). It is a 25-item scale which covers aspects such as psychopathy (7-items), narcissism (9-items), and Machiavellianism (9-items). Responses are made on a 4 point response format ranging from 1 (strongly disagree) to 4 (strongly agree). Some of the items are reverse scored. A sample item includes "It's not wise to tell your secrets", while an example of the item with reverse scoring is "I hate being the center of attention". Cronbach alpha for the Machiavellianism, narcissism, and psychopathy scales were $0.71,0.76$, and 75 respectively. Factor analysis also showed alignment to the three dimensions identified by Jones and Paulhus (2014). 
Experience with the Police Items were drawn from the Police Survey for England and Wales. The experience with the police (EwP) scale is a 7-itemed scale highlighting various encounters with the police including being questioned, searched, arrested, or detained by the police. Responses are given on a Likert scale of never (0), once (1), twice (2), and thrice or more (3) with higher scores indicating more encounter with the police. It does not explicitly point to a positive or negative experience, rather higher scores indicate having more encounter with the police. Sample items include "Have you had an encounter with the police" and "Have you ever been questioned by the police". Item analysis on the scale yielded a Cronbach's alpha of 0.76 . Factor analysis on the scale also confirmed a single factor structure.

Police Perception Scale As no specific comprehensive scale was found to assess police perception, approximate scales that utilized items close to the construct were pulled together to assess police perception. Items were picked from the police legitimacy scale, a 4-item scale developed by Ferdik (2014); the general attitude toward and specific trust in the police officers measure (GASTP) Lai and Zhao (2010); the confidence in police index scale (CP), Ren et al. (2005); the perception of police integrity measure (PPI) by Wu (2010); and the attitudes toward police misconduct measure (ATPMM) Dowler and Zawilski (2007). Sample items include "How often do you believe police officers will bend the rules to get a confession from a person accused of crime" and "How often do you think police officers physically abuse those who are accused of a crime". Items were scored such that higher scores indicated better perception of the police. Items were screened for repetition and ambiguousness. Items were also screened for face validity by experts in psychometrics. Twenty-eight items were selected in all based on corrected item total scores (>0.3). Cronbach's alpha for the assembled scales was 0.896 . Factor analysis on the scale supported a single factor solution.

\section{Procedure}

The researchers administered the questionnaires to 300 individuals which included undergraduates from different faculties of the University of Nigeria, Nsukka and also to workers from different organizations within Enugu. Participants completed consent forms. The researchers received the assistance of the departmental class representatives in distributing the questionnaires to their students within their lecture periods. The nature of the study was explained to the participants in written instructions, and they were sufficiently guided in completing the instruments. The questionnaires were collected immediately after completion, and the participants were verbally appreciated for their participation. Of the 300 copies of the questionnaire that were distributed, 261 were returned and were appropriately completed and used in data analysis.

\section{Design/Statistics}

The study employed a cross-sectional design. The statistics used to test the hypotheses was regression analysis. After considering missing data, 207 participants qualified for the regression analysis. Descriptive and zero order correlation of police perception, age, gender, experience with the police, Machiavellianism, narcissism, and psychopathy is presented first. This is followed by the results of statistical analysis performed to test the hypotheses (see Table 1).

The correlation table show that age $(r=-0.14, p=0.02)$, experience with the police $(r=-0.15, p=0.01)$, and narcissism $(r=-0.15, p=0.02)$ were negatively and significantly related to police perception. Interestingly as scores on these variables increased, police approval ratings decreased as the intercorrelations among these variables were negative. Other interesting significant correlating patterns were psychopathy scores were related to Machiavellianism scores $(r=0.15, p=$ 0.01) (see Table 2).

Result from the regression analysis showed that age negatively and significantly predicted experience with the police such that the older a person is, the more negatively the police is perceived $(\beta=-0.19, t=-2.06, p=0.04)$. Also in the second model, having an encounter with the police negatively predicted police perception $(\beta=-0.16, t=-1.97, p=0.04)$. Hence, the more encounter people had with the police the poorer their perception about the police. This suggets that many encounters with the police were negative. Finally among the dark triad traits, only narcissism predicted police perception such that higher narcissism traits culminated in a more negative perception of the police $(\beta=-0.46, t=-2.21$, $p=0.03)$.

\section{Discussion}

This study investigated the roles of dissocial personality traits and experience with the police on how people perceived the

Table 1 Descriptive and zero order correlation table among demographics and main study variables

\begin{tabular}{lllllll}
\hline Variables & 1 & 2 & 3 & 4 & 5 & 6 \\
\hline 1. Police perception & - & & & & & \\
2. Age & $-0.13^{*}$ & - & & & & \\
3. Gender & -0.05 & $0.27^{* *}$ & - & & & \\
4. Exp with police & $-0.17^{*}$ & $0.28^{* *}$ & $0.44^{* *}$ & - & & \\
5. Machiavellianism & 0.02 & $-0.11^{*}$ & $0.12^{*}$ & 0.08 & - & \\
6. Narcissism & $-0.17^{*}$ & 0.07 & 0.04 & 0.10 & 0.07 & - \\
7. Psychopathy & 0.04 & 0.03 & 0.08 & 0.09 & $0.15^{*}$ & 0.03 \\
\hline
\end{tabular}

$* P<0.05, * * P<0.001$ 
Table 2 Regression table predicting police perception from demographics and main study variables

\begin{tabular}{llllll}
\hline Model & Variables & $R$ & $R^{2} \Delta$ & $\beta$ & $t$ \\
\hline 1. & Age & 0.13 & 0.02 & -0.19 & $-2.06^{*}$ \\
& Gender & & & 0.02 & 0.30 \\
2. & Experience with police & 0.20 & 0.02 & -0.16 & $-1.97^{*}$ \\
3. & Psychopathy & 0.25 & 0.02 & 0.17 & 0.07 \\
& Narcissism & & & -0.46 & $-2.21^{*}$ \\
& Machiavellianism & & & 0.18 & 0.43 \\
\hline
\end{tabular}

$* P<0.05$

police. The first hypothesis which stated that dissocial traits would not significantly predict police perception was not confirmed because at least one of the dissocial traits, narcissism, negatively and significantly predicted police perception. Among the dark triad traits, only narcissism predicted police perception such that higher narcissism traits culminated in more negative perception of the police. This implies that individuals with higher narcissism traits were more likely to perceive the police in negative light. This result is in agreement with previous findings. For instance, Campbell and Foster (2007) found that narcissists tend to view the police in a less favorable way. Persons with narcissistic traits demonstrate a lack of interest in warm and caring interpersonal relationships. They also find it difficult to get involved in relationships between two or more people because of they are full of egoism and pride. Our finding further demonstrates that apart from the activities of the police, individual factors such as personality could influence how the police is seen. Stretching the implication of this finding, persons who are likely to perceive the police in negative light, may also tend to comply less, or even act negatively towards them. Rigby and Rump (2010) had found that personality factors are linearly related to attitude towards authority.

Previous studies have not highlighted how persons with psychopathic traits typically percive the police. Though psychopathic traits (and its related callous unemotional traits in youths) is widely recognised to be associated with disruptive behaviours such aggression (Orjiakor et al. 2020) and serious criminal offending (Dhingra and Boduszek 2013; McCuish et al 2015), it was rather surprising to notice that it did not predict the perception of the police. This finding may however align with Brankley and Rule (2014), who found that psychopathy is associated with a bias to see others as unthreathening. Brankley and Rule equally found that Machiavellianism was highly associated with psychopathy, and this may also explain why the former personality trait failed to predict police perception. The second hypothesis which stated that experience with the police would not significantly predict police perception was also not confirmed because experience with the police negatively and significantly predicted police perception. We found that participants' experience with the police negatively impacted how they saw the police. Thus the more contacts they had with the police, the more they resent the police. This implies that contact with the police in Nigeria leaves citizens with a bad taste. This is not surprising giving the high rates of reports on police brutality and police involvement in corruption in the country. Previous Nigerian studies on the police share the same findings (Ajomo and Okagbue 1991; Alemika 1988; Alemika and Chukwuma 2000; IbidapoObe 1991; Nwokeoma et al. 2019; Onyishi et al. 2020). Nigeria is currently ranked as the worst country in the World Internal Security and Police Index (IPSA 2016). This is a strong message to the management of the Nigerian Police Force, related organisations, as well as policy makers who influence policing policies in Africa's most populous country. There is a strong need to constatntly examine and improve policing in the country. Slightly similar findings have been found in literature. In Canada, respondents were only marginally positive in their evaluations of the police (Chow 2011); Canadian adolescents who were older and those who held more positive school attitudes, experienced no police mistreatment or harassment, reported no criminal victimization, and exhibited lower propensity to engage in unlawful activities were found to rate the overall police performance significantly more favorably (Chow 2011). In India (Singh 1998) and in Easter Europe (Land 1998), low evaluations of the police, which were most likely due to respondents' knowledge of, or experience with, corrupt or brutal officers have also been reported. Brandt and Markus (2000) indicated that adolescents who reported negative experiences with the police had less favorable attitude toward the police. Thus experience with the police is a key concern in how the police is perceived. Police organisations should then do well to ensure that they invest in trainings/interventions that will improve their modus operandi as well as their professionalism in order to positively engage with the public.

Participants were drawn from a State in Nigeria, menaing that our findings may be taken with caution. We also deployed a cross-sectional design which mean that causal inferences may not be made. Future studies can expand the sample size and accommodate, perhaps experimental designs. As with most self-report studies, participants may have presented themselves in a more favorable light, downplaying the presence of dissocial traits and compromising the links between other dissocial traits and police perception. Also, getting individuals to provide sincere answers to survey questions is difficult even though confidentiality is assured; as a result, some participants could have randomly rated themselves without reading the questions. 


\section{Conclusions}

The study investigated the relationship between dissocial traits and experience with the police and police perception. Dissocial traits particularly narcissism was negatively associated with police perception. Experience with the police was a negative predictor of police perception; this implies that the more encounter people had with the Nigerian police, the poorer their perception about the police. Police organizations, especially in Nigeria should strive to improve in their relation to citizens as this will ensure better coorporation and effectiveness in delivering services. A qualitative assessment of experiences with the police and how it impacts relationship with the poilce is a worthy pursuit, especially in Nigeria. Identifying areas that Police organizations can leverage to improve their connectedness to citizens have potentials to improve the perception of the police.

\section{Compliance with Ethical Standards}

Conflict of Interest The authors declared that they have no conflict of interest.

Ethical Approval The researchers obtained written approval letter from Research and Ethics Committee, of the Department of Psychology, University of Nigeria to conduct the study.

Informed Consent Participants completed consent forms.

\section{References}

Ajomo MA, Okagbue IE (1991) Human rights and criminal justice administration in Nigeria. Nigerian Institute of Advanced Legal Studies, Lagos, p 122

Alemika EEO (1988) Policing and perceptions of police in Nigeria. Police Studies 11:161-176

Alemika EEO, Chukwuma IC (2000) Police-Community violence in Nigeria. Centre for Law Enforcement Education (CLEEN), Ikeja

American Psychological Association (2010) Ethical Principles of Psychologists and Code of Conduct. Retrieved from https://doh.dc. gov/sites/default/files/dc/sites/doh/publication/attachments/ ETHICAL\%20PRINCIPLES\%20OF\%20PSYCHOLOGISTS\% 20and\%20CODE\%20OF\%20CONDUCT.pdf

Amnesty International (2014). Retrieved from : https://www.amnesty. org/download/Documents/4000/afr440052014en.pdf. Accessed 13 Apr 2020

Andvig, J.C. \& Fjeldstad, O.H. (2008). Crime, poverty and police corruption in developing countries. Chr. Michelsen Institute. Retrieved from: https://www.cmi.no/publications/file/3076-crime-povertypolice-corruption-in-developing.pdf. Accessed 4 Feb 2018.

Augustyn MB, Ray JV (2016) Psychopathy and perceptions of procedural justice. J Crim Justice 46:170-183

Brandt, D.E., \& Markus, K.A.J. (2000). Police criminal psychology, 15,10

Brankley AE, Rule NO (2014) Threat perception: how psychopathy and Machiavellianism relate to social perceptions during competition. Pers Individ Differ 71:103-107
British Broadcasting Coorporation (2020) Coronavirus: security forces kill more Nigerians than Covid-19. Retrieved from https://www. bbc.com/news/world-africa-52317196. Accessed 02 Aug 2020

Campbell, W.K., \& Foster, J. D. (2007). The narcissistic self: background and extended agency model and ongoing controversies. Sedikides and Spencer. The Self, Psychology Press

Chatham House (2010) Nigeria's Police Force: Corruption and Reform. Retrieved from https://www.chathamhouse.org/events/view/ 156817

Cheng H (2015) Factors influencing publicsatisfaction with the local police:a study in Saskatoon, Canada. Policing: An International Journal of Police Strategies \& Management 38(4):690-704. https://doi.org/10.1108/PIJPSM-11-2014-0125

Cheurprakobkit S (2000) Police-citizen contact and police performance: attitudinal differences between Hispanics and non-Hispanics. J Crim Just 28:325-336

Chow HPH (2011) Adolescent attitude toward the police in a western Canadian city. Policing: An international journal of police strategies and management 34:638-653

Dean D (1980) Citizen ratings of the police: the difference contact makes. Law Policy Q 2:445-471

Decker, S.H. (1985). The police and the public: perceptions and policy recommendations, in Homant, R.J. and Kennedy, D.B. (Eds). Police Law Enforcement, 3, 89-105

Dhingra K, Boduszek D (2013) Psychopathy and criminal behaviour: a psychosocial research perspective. J Crim Psychol 3(2):83-107

Dowler K, Zawilski V (2007) Public perceptions of police misconduct and discrimination: examining the impact of media consumption. J Crim Just 35(2):193-203

Egwu P (2020) As the world matches for American victims, police brutality in Africa goes unnoticed. Foreign Policy. Retrived from https://foreignpolicy.com/2020/06/17/black-lives-matter-protestsafrica-police-brutality/. Accessed 2 Aug 2020

Eze JE, Orjiakor CT, Iorfa SK, John C (2020) Beyond criminality: exploring associations between psychopathic traits and lifestyles among non-offenders in sub-Saharan Africa. J Forensic Psychiatry Psychol 31(4):473-489

Ferdik FV (2014) The influence of strain on law enforcement legitimacy evaluations. J Crim Just 42(6):443-451

Human Rights Watch (2005) "Rest in Pieces" Police Torture and Deaths in Custody in Nigeria. Retrieved from https://www.hrw.org/reports/ 2005/nigeria0705/nigeria0705.pdf

Human Rights Watch (2010) Everyone's in on the game, corruption and human rights abuses by the Nigeria Police Force. http://www.hrw.org. Accessed 11 May 2010

Ibidapo-Obe (1991) Police brutality: dimensions and control in Nigeria. In: Innocent C, Ibidapo-Obe A (eds) Law enforcement and human rights in Nigeria. Civil Liberties Organisation, Lagos

International Police Science Association (2016) World internal security and policing index. Retrieved from http://www.ipsapolice.org/ Images/uploaded/Pdf\%20file/WISPI\%20Report.pdf

Jacobwitz S, Egan V (2006) The 'dark triad' and normal personality traits. Personal Individ Differ 40(3):331-339

Johnson JA, Hogan R, Zonderman AB, Callens C, Rogolsky S (1981) Moral judgment, personality, and attitudes toward authority. J Pers Soc Psychol 40(2):370

Johnson, O.A., \& Olukayode, L. (2014). Public perception of the police and crime prevention in Nigeria. Department of sociology, faculty of the social sciences, Ekiti state University, Ado - Ekiti, Nigeria

Jones DN, Paulhus DL (2014) Introducing the short dark triad (SD3): a brief measure of dark personality traits. Assessment 21(1):28-41

Konut H (1977) The restoration of the self. International University Press, New York

Lai YL, Zhao JS (2010) The impact of race/ethnicity, neighborhood context, and police/citizen interaction on residents' attitudes toward the police. J Crim Just 38(4):685-692 
Land T (1998) Eastern Europe's police forces court public opinion. Contemp Theatr Rev 273(295-8):1595

Lee J, Gibbs JC (2015) Race and attitudes toward police: the mediating effect of social distance. Policing: An International Journal of Police Strategies \& Management 38(2):314-332. https://doi.org/10.1108/ PIJPSM-03-2015-0034

MacDonald J, Stokes RJ, Ridgeway G, Riley KJ (2007) Race, neighbourhood context and perceptions of injustice by the police in Cincinnati. Urban Stud 44(13):2567-2585

McCuish EC, Corrado RR, Hart SD, DeLisi M (2015) The role of symptoms of psychopathy in persistent violence over the criminal career into full adulthood. J Crim Justice 43(4):345-356

Nwokeoma BN et al (2019) Impact of rational emotive occupational health coaching on work-related stress management among staff of Nigerian Police Force. Medicine. https://doi.org/10.1097/MD. 0000000000016724

Obe, E. \&Odesola, T. (2008). Policeman kills cyclist over alleged N20 bribe. Punch, November 4, 2008, http://www.punchng.com/Articl. aspx?theartic $=$ Art20081104385248 $($ accessed December 4, 2009)

Onyedire NG, Chukwuorji JC, Orjiakor TC, Onu DU, Aneke CI, Ifeagwazi CM (2019) Associations of Dark Triad traits and problem gambling: moderating role of age among university students. Curr Psychol:1-12. https://doi.org/10.1007/s12144-018-0093-3

Onyishi et al (2020) Rational emotive occupational health coaching in the management of police subjective well-being and work ability: a case of repeated measures. https://doi.org/10.1007/s11896-019-09357-y

Orjiakor CT, Weierstall R, Bowes N, Eze JE, Ibeagha PN, Obi PC (2020) Appetitive aggression in offending youths: Contributions of callous unemotional traits and violent cognitive patterns. Curr Psychol. https://doi.org/10.1007/s12144-020-00759-4

Ren L, Cao L, Lovrich N, Gaffney M (2005) Linking confidence in the police with the performance of the police: community policing can make a difference. J Crim Just 33(1):55-66
Rigby K, Rump EE (2010) Attitudes toward authority and authoritarian personality characteristics. J Soc Psychol 116(1):61-72

Singh OR (1998) People's perceptions of women police in Delhi. Social Welfare 45:25-30

Skeem, J.L., Polaschek, D.L.L., Patrick, C.J., \& Lilienfeld, S.O. (2011). Psychopathic personality: bridging the gap between scientific evidence and public psychological science in the public interest

Smith DJ (1991) The origins of black hostility to the police. Polic Soc 2: $1-15$

Smith PE, Hawkins RO (1973) Victimization, types of citizen-police contacts and attitudes toward the police. Law Soc Rev 8:135-152

Thomas CW, Hyman JM (1977) Perceptions of crime, fear of victimization, and public perceptions of police performance. J Police Sci Adm 5:05-17

Worrall JL (1999) Public perceptions of police efficacy and image: the 'fuzziness' of support for the police. Am J Crim Justice 24:47-66

Wu Y (2010) College students' evaluation of Police performance: a comparison of Chinese and Americans. J Crim Justice 38(4):773-780. https://doi.org/10.1016/j.jcrimjus.2010.05.004

Zeigler-Hill V, Martinez JL, Vrabel JK, Ezenwa MO, Oraetue H, Nweze T, Andrews D, Kenny B (2020) The darker angels of our nature: Do social worldviews mediate the associations that dark personality features have with ideological attitudes?. Pers Individ Differ 160: 109920

Zhao JS, Tsai CF, Ren L, Lai YL (2014) Public satisfaction with police control of disorder crime: does the public hold police accountable? Justice Q 1(2):394-420

Publisher's Note Springer Nature remains neutral with regard to jurisdictional claims in published maps and institutional affiliations. 